\title{
The relationship between plasma $\beta$ - hydroxybutyric acid and conjugated linoleic acid in milk as a biomarker for early diagnosis of ketosis in postpartum Polish Holstein-Friesian cows
}

\author{
Kamila Puppel ${ }^{* \dagger}$ (D, Marcin Gołębiewski ${ }^{\dagger}$, Paweł Solarczyk, Grzegorz Grodkowski, Jan Slósarz, \\ Małgorzata Kunowska-Slósarz, Marek Balcerak, Tomasz Przysucha, Aleksandra Kalińska and Beata Kuczyńska
}

\begin{abstract}
Background: The aim of this study was to investigate the association between plasma $\beta$-hydroxybutyric acid (BHBA) and conjugated linoleic acid in postpartum Polish Holstein-Friesian (PHF) cows. The experiment was carried out at an experimental dairy farm, where a herd of approximately 350 cows was kept. Samples were taken at six time points: between days 5-7, 8-14, 15-21, 22-28, 29-35, and 36-42, resulting in 510 samples of both milk and blood. The cows involved in the experiment were divided into two groups - ketotic and healthy - by taking into account general health symptoms, blood serum BHBA, and non-esterified fatty acids (NEFA) concentration at 5-7 days postpartum.
\end{abstract}

Results: In the first week of lactation, at 5-7 day in milk (DIM), the study showed a 53\% lower level of C18:2 cis-9 trans-11 (CLA9) and an 80\% lower level of C18:2 trans-10 cis-12 (CLA10) in cows with diagnosed ketosis compared to healthy cows. In the second week of lactation (8-14 DIM), a 34\% lower level of CLA9 and a 54\% lower level of CLA10 was found in the group of cows with BHBA levels $>1.2 \mathrm{mmol} / \mathrm{L}$. Additionally, Pearson correlation analysis showed significant negative correlation between BHBA $\times$ CLA9 and BHBA x CLA10 in the first week of lactation:0.732 and -0.821 , respectively.

Conclusion: The study shows that that both CLA9 and CLA10 can be used as markers for the early diagnosis of elevated blood levels of BHBA in postpartum Polish Holstein-Friesian cows.

Keywords: Cow, $\beta$-Hydroxybutyric acid, Conjugated linoleic acid, Ketosis, Milk

\section{Background}

Ketosis is considered to be the most important metabolic disease affecting dairy herds, surpassing ruminal acidosis and milk fever [1]. In regards to diagnosis, ketosis can be divided into clinical ketosis, in which the symptoms are easy to recognize and diagnose, and subclinical ketosis, which is more common in high-production farms. In subclinical ketosis, there is an elevated level of ketone bodies

\footnotetext{
*Correspondence: kamila_puppel@sggw.pl

${ }^{+}$Kamila Puppel and Marcin Gołębiewski contributed equally to this work. Animal Breeding and Production Department, Warsaw University of Life Sciences, Ciszewskiego 8, 02-786 Warsaw, Poland
}

and a reduced level of glucose, however, the cow does not yet show signs of clinical ketosis. Subclinical ketosis can occur in up to $60 \%$ of cows in a herd, and clinical ketosis from 2 to 15\% [2]. Ketone bodies are a group of organic compounds that are intermediate metabolites of fat. These include acetone (formed as a result of spontaneous decarboxylation of acetoacetate), acetoacetic acid (in the form of anion- acetoacetate) and $\beta$-hydroxybutyric acid (BHBA, in the form of anion- $\beta$-hydroxybutyrate).

The profiles of milk fatty acids are closely related to energy balance in dairy cows, and milk fatty acids are interesting biomarkers for ketosis and negative energy balance

(c) The Author(s). 2019 Open Access This article is distributed under the terms of the Creative Commons Attribution 4.0 International License (http://creativecommons.org/licenses/by/4.0/), which permits unrestricted use, distribution, and 
(NEB) [3]. The fatty acid synthesis pathway involves the following steps: activation (acetyl-CoA carboxylation), elongation (malonyl-CoA pathway), condensation, reduction, dehydration and another reduction [4-7]. During NEB, NEFA in blood plasma increase and the fatty acid supply to the mammary glands is altered. NEFA released from lipolysis are mainly C16:0, C18:0 and C18:1 cis-9, with a further possible conversion of C18:0 to C18:1 cis-9 in the mammary glands through the action of $\Delta 9$ desaturase [8]. Milk fatty acids are of growing interest in the detection of elevated blood plasma BHBA and NEFA [9-11]. There are four major pathways that create milk fatty acids: diet, de novo synthesis in the mammary glands, and formation in the rumen by biohydrogenation or bacterial degradation [12]. According to Čejna and Chladek [13], the NEB stage is associated with a high ratio of growth hormone to insulin in the blood, which induces the mobilization of long-chain fatty acids from fatty tissue. Puppel et al. [14] reported that C18:1 cis9 may be used as a biomarker for the early diagnosis of elevated blood levels of NEFA during the early stages of lactation in high-yield PHF cows. The highest levels of NEFA in the blood were associated with the highest content of C18:1 cis-9 in milk fat, which exceeded $24 \mathrm{~g} / 100 \mathrm{~g}$ of fat.

During ketogenesis, mitochondrial $\beta$-oxidation of longchain acids occurs in the liver. According to Foster [15], long-chain fatty acids are transported to mitochondria via carnitine-palmitoyltransferase, which is regulated by the concentration of malonyl-CoA. The first step of ketogenesis relies on the condensation of two molecules of acetylCoA to form acetoacetyl-CoA. The third acetyl-CoA molecule is attached to 3-hydroxy-3-methylglytaryl-CoA (HMG-CoA) by mitochondrial HMG-CoA synthetase. Then, HMG-CoA is converted into acetoacetate by HMG-CoA lyase. In turn, acetoacetate is reduced to BHBA by NADH-dependent $\beta$-hydroxybutyrate dehydrogenase [16]. The rate of formation of ketone bodies is conditioned by the rate of the conversion of fatty acids into ketone bodies rather than the spawning of the $\beta$-oxidation process [17]. In turn, high concentrations of ketone bodies decrease the rate of $\beta$-oxidation of fatty acids [18-20].

BHBA is of a higher concentration in the blood of cows that have energy deficiency and is considered to be an indicator of subclinical ketosis [21]. Studies have shown that clinical ketosis in dairy cows generally occurs between week two and seven after calving [22]. BHBA concentrations of $<2.6$ and $>1.2 \mathrm{mmol} / \mathrm{L}$ in the first week of the postpartum period are indicative of subclinical ketosis [21-23]. BHBA is synthesized both in the process of ketogenesis, as well as in the rumen through butyrateproducing bacteria [23]. Additionally, Melendez et al. [24] reported that all bacteria that produced CLA cis-9, trans11 from linoleic acid were butyrate producers.
Ketosis can be monitored using blood, urine, or milk samples. The method of diagnosing ketosis, based on the milk fat/protein ratio, is limited: sensitivity of $58 \%$ and specificity of $69 \%$ [1]. Periodic herd blood testing for BHBA concentration is the easiest way to early detection of ketosis in cattle, but BHBA in plasma is not a cost effective or convenient analysis [25]. Various cowside tests are available to monitor the ketosis of dairy herds. However, none of the cowside tests have a perfect sensitivity and specificity compared to blood BHBA [26-28]. Therefore, it is important that new tests with greater sensitivity and specificity need to be developed.

\section{The aim of this study}

The aim of this study was to investigate the association betweenplasma BHBA and conjugated linoleic acid in postpartum PHF cows.

\section{Results}

Figures 1, 2 and 3 show changes in gross milk composition in the first 42 days of lactation. The protein content of the milk at 5-7 DIM was $3.77 \%$ in cows with a BHBA level $>1.2 \mathrm{mmol} / \mathrm{L}$, and gradually decreased to a level of $2.94 \%$ at 36-42 DIM (Fig. 1). The fat content of the milk at 5-7 DIM was $5.49 \%$ in cows with a BHBA level $>1.2$ $\mathrm{mmol} / \mathrm{L}$. Over the next few weeks, the fat concentration decreased to a level of $4.08 \%$ at 36-42 DIM (Fig. 2). The highest $\mathrm{F} / \mathrm{P}$ ratio (1.56) was demonstrated in the first period - between the fifth and seventh days of lactation in cows with a BHBA level $>1.2 \mathrm{mmol} / \mathrm{L}$ (Fig. 3).

In the Table 1 concentration of selected fatty acid (g/ 100 gof fat) of both group in the first 14 days of lactation has been presented. Studies have shown that the concentrations of C4:0, C6:0, C8:0, C10:0, C12:0 and C14:0 are significantly influenced by BHBA.

For the first week of lactation (5-7 DIM), studies have shown a $5 \%$ lower level of C18:2 n-6 (LA) in cows with a BHBA level $>1.2 \mathrm{mmol} / \mathrm{L}$. In the second week of lactation (8-14 DIM), a $20 \%$ higher level has been found in cows with a BHBA concentration in the range of 0.51$1.2 \mathrm{mmol} / \mathrm{L}$ (Fig. 4). LA was significantly influenced by both, the lactation phase and BHBA.

The first week of lactation (5-7 DIM) showed a 51\% lower level of C18:2 cis-9 trans-11(CLA9) in cows with a BHBA level $>1.2 \mathrm{mmol} / \mathrm{L}-$ so in cows with diagnosed ketosis. However, in the second week of lactation (8-14 DIM), a 34\% lower level in the second group was demonstrated (Fig. 5). There were significant differences in the CLA9 content between the analysed groups.

The first week of lactation (5-7 DIM) showed an 80\% lower level of C18:2 trans-10 cis-12 (CLA10) in cows with a BHBA level $>1.2 \mathrm{mmol} / \mathrm{L}$. In the second week of lactation, a 54\% lower level was also found in this group 


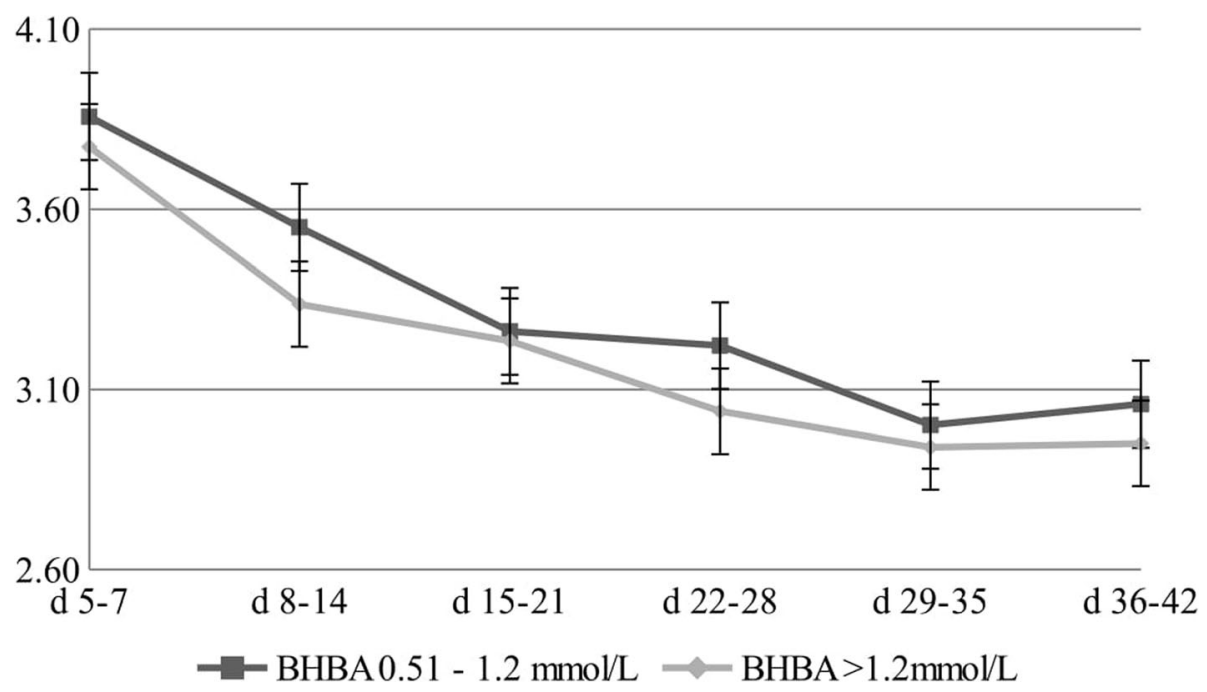

Fig. 1 Changes in protein level [\%] for different concentrations of BHBA

(Fig. 6). There were significant differences in the content CLA10 between the analysed groups.

Pearson correlation analysis showed a significant negative correlation between BHBA levels and the levels of selected functional fatty acids (Tables 2 and 3). Strong negative correlation in the first week of lactation (5-7 DIM) was found between BHBA x CLA9 (-0.732; $p \leq$ $0.01)$ and BHBA $x$ CLA10 ( $-0.821 ; \mathrm{p} \leq 0.01)$, and in the second week of lactation between BHBA x CLA9 (0.520; $\mathrm{p} \leq 0.01)$ and BHBA x CLA10 (-0.635; $\mathrm{p} \leq 0.01)$.

\section{Discussion}

Clinical ketosis most frequently occurs in susceptible highyield dairy cows in the first days of lactation as a consequence of inadequate nutrition and management [9, 19, 21]. Clinical features include anorexia, depression, and metabolic disease. Cows also have low milk production and poor reproductive capacity [29]. High levels of BHBA induce hepatic oxidative stress, apoptosis, and inflammation [30]. Therefore, rapid diagnosis of ketosis is very important.

There were significant differences in the protein content between the analysed groups. Similar relations were demonstrated by Ikoen et al. [31] and Peckaet al [32].. These authors found that the protein concentration in milk stabilizes after the sixth week of lactation. Based on the results obtained, it can be concluded that the reduction in the level of protein in subsequent collections was caused by a dilutioneffect, and the reduction in the

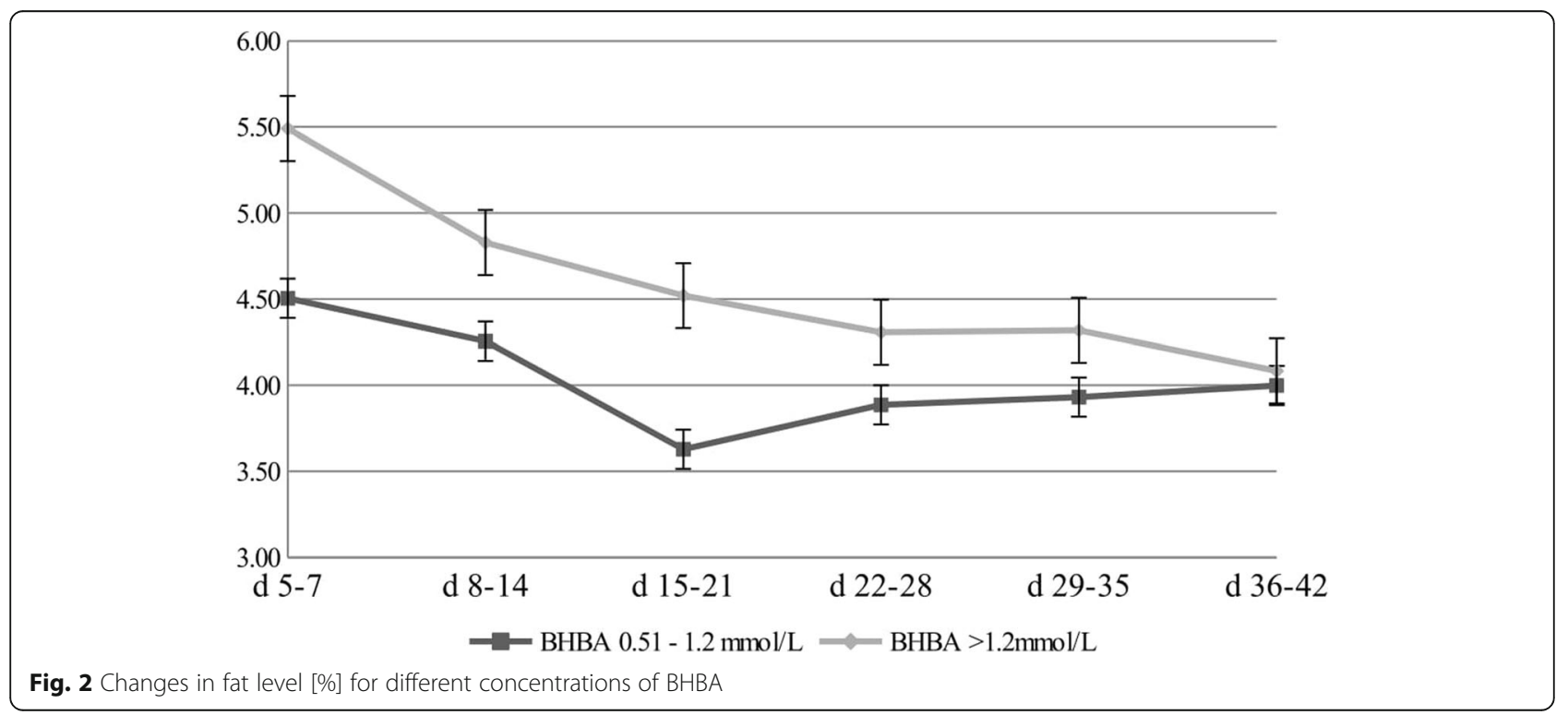




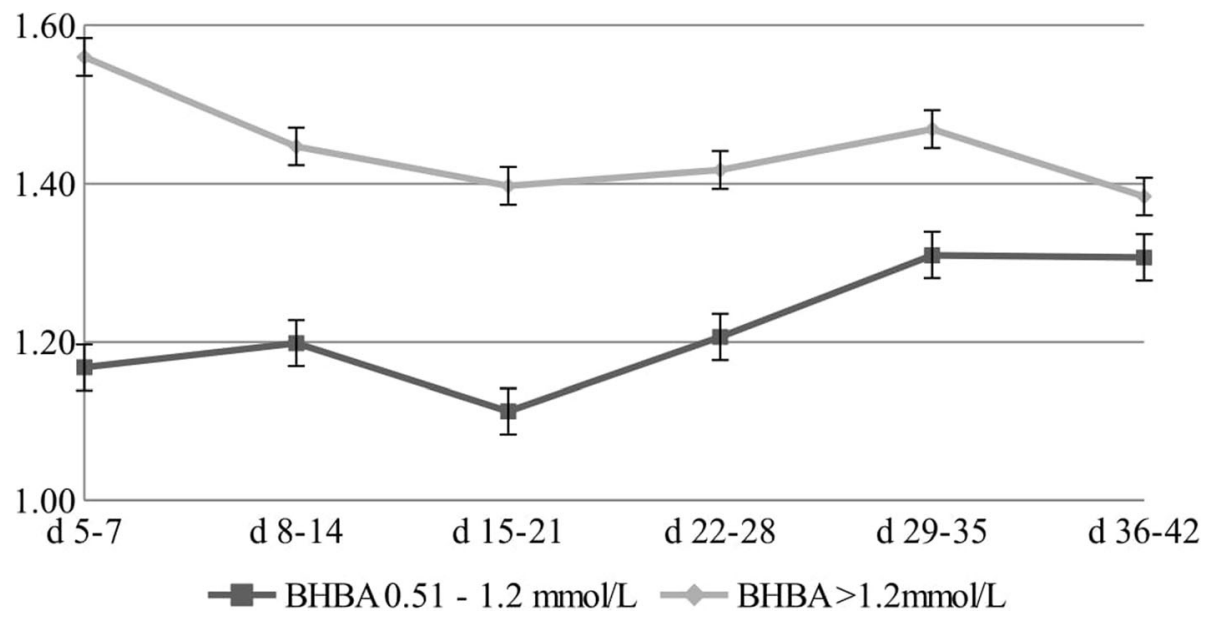

Fig. 3 Changes in F/P ratio for different concentrations of BHBA

concentration of this milk ingredient was the result of an increase in the cows' total milk yield.

Fourier transform infrared spectrum of milk and milk composition could be used by breeders to predict blood BHBA levels, because these data are available during Dairy Herd Improvement testing [33]. The protein content of the milk at 5-7 DIM was $3.77 \%$ in cows with a BHBA level > $1.2 \mathrm{mmol} / \mathrm{L}$, and gradually decreased to a level of $2.94 \%$ at 36-42 DIM (Fig. 1). Heuer et al. [34] suggested that changes in gross composition of milk are useful risk predictors for energy balance in early lactation, e.g. fat/protein ratio $>1.4$, milk protein $<2.9 \%$, and milk fat $>4.8 \%$.

There were significant differences in the fat content of milk between the analysed groups. The fat content of the milk at 5-7 DIM was $5.49 \%$ in cows with a BHBA level $>1.2 \mathrm{mmol} / \mathrm{L}$. Duffield et al. [35] showed a direct relationship between BHBA and fat content. Cows with a BHBA level $>0.7 \mathrm{mmol} / \mathrm{L}$ were characterized by a fat

Table 1 Changes in selected fatty acid composition $[\mathrm{g} / 100 \mathrm{~g}$ of fat] for different concentrations of BHBA in the first 14 days of lactation

\begin{tabular}{|c|c|c|c|c|c|}
\hline Component & $\begin{array}{l}\text { BHBA } 0.51-1.2 \mathrm{mmol} / \mathrm{L} \\
\text { d } 5-7\end{array}$ & $\mathrm{BHBA}>1.2 \mathrm{mmol} / \mathrm{L}$ & $\begin{array}{l}\text { BHBA } 0.51-1.2 \mathrm{mmol} / \mathrm{L} \\
\mathrm{d} 8-14\end{array}$ & $\mathrm{BHBA}>1.2 \mathrm{mmol} / \mathrm{L}$ & SEM \\
\hline$C 4: 0$ & $2.821^{\mathrm{A}}$ & $2.392^{\mathrm{A}}$ & $2.920^{\mathrm{A}}$ & $2.475^{\mathrm{A}}$ & 0.0963 \\
\hline C6:0 & $1.550^{\mathrm{A}}$ & $1.356^{\mathrm{A}}$ & $1.761^{\mathrm{A}}$ & $1.296^{\mathrm{A}}$ & 0.0960 \\
\hline $\mathrm{C} 8: 0$ & $1.239^{\mathrm{A}}$ & $0.902^{A}$ & $1.269^{A}$ & $1.028^{A}$ & 0.0768 \\
\hline C10:0 & $2.379^{\mathrm{A}}$ & $1.830^{\mathrm{A}}$ & $1.767^{\mathrm{A}}$ & $2.014^{\mathrm{A}}$ & 0.1154 \\
\hline $\mathrm{C} 12: 0$ & $2.718^{\mathrm{a}}$ & $2.528^{a}$ & $2.653^{a}$ & $2.468^{\mathrm{a}}$ & 0.1311 \\
\hline C14:0 & $9.357^{a}$ & $8.818^{a}$ & 9.239 & 9.094 & 0.3331 \\
\hline C16:0 & 29.801 & 30.440 & 32.420 & 31.001 & 0.8070 \\
\hline C16:1 & $1.495^{\mathrm{A}}$ & $2.004^{\mathrm{A}}$ & 1.858 & 1.840 & 0.0131 \\
\hline $\mathrm{C} 17: 0$ & 0.624 & 0.590 & 0.627 & 0.619 & 0.0240 \\
\hline C18:0 & 17.734 & 17.908 & 17.601 & 17.834 & 0.2729 \\
\hline C18:1 C9 & $23.581^{\mathrm{A}}$ & $25.241^{\mathrm{A}}$ & $25.360^{A}$ & $27.262^{\mathrm{A}}$ & 0.6752 \\
\hline C18:3 n6 & $0.032^{\mathrm{A}}$ & $0.049^{A}$ & 0.054 & 0.050 & 0.0063 \\
\hline C20:4 n6 & $0.166^{\mathrm{A}}$ & $0.137^{\mathrm{A}}$ & 0.161 & 0.158 & 0.0072 \\
\hline C20:5 n3 & 0.088 & 0.076 & 0.090 & 0.087 & 0.0040 \\
\hline C22:5 n3 & 0.069 & 0.065 & 0.055 & 0.045 & 0.0008 \\
\hline
\end{tabular}

Samples of milk and blood were collected from the cows for laboratory analyses at weekly intervals. Samples were taken at six time points: between days 5-7, 8$14,15-21,22-28,29-35$, and 36-42. The cows involved in the experiment were divided into two groups - ketotic (BHBA $>1.2 \mathrm{mmol} / \mathrm{L}$ and NEFA $\geq 0.7 \mathrm{mmol} / \mathrm{L}$ at $5-7$ days postpartum) and healthy (BHBA $0.51-1.2 \mathrm{mmol} / \mathrm{L}$ and NEFA $<0.7 \mathrm{mmol} / \mathrm{L}$ at $5-7$ days postpartum) Data were presented as LSM with SEM

NEFA Nonesterified fatty acids, BHBA $\beta$-hydroxybutyric acid, DIM Days in milk, LSM Least square of mean, SEM Standard error of LSM

${ }^{\mathrm{aA}}$ Means in the same rows (for selected DIM) marked with the same letters differ significantly at: small letters $-P \leq 0.05$; capitals- $P \leq 0.01$ 


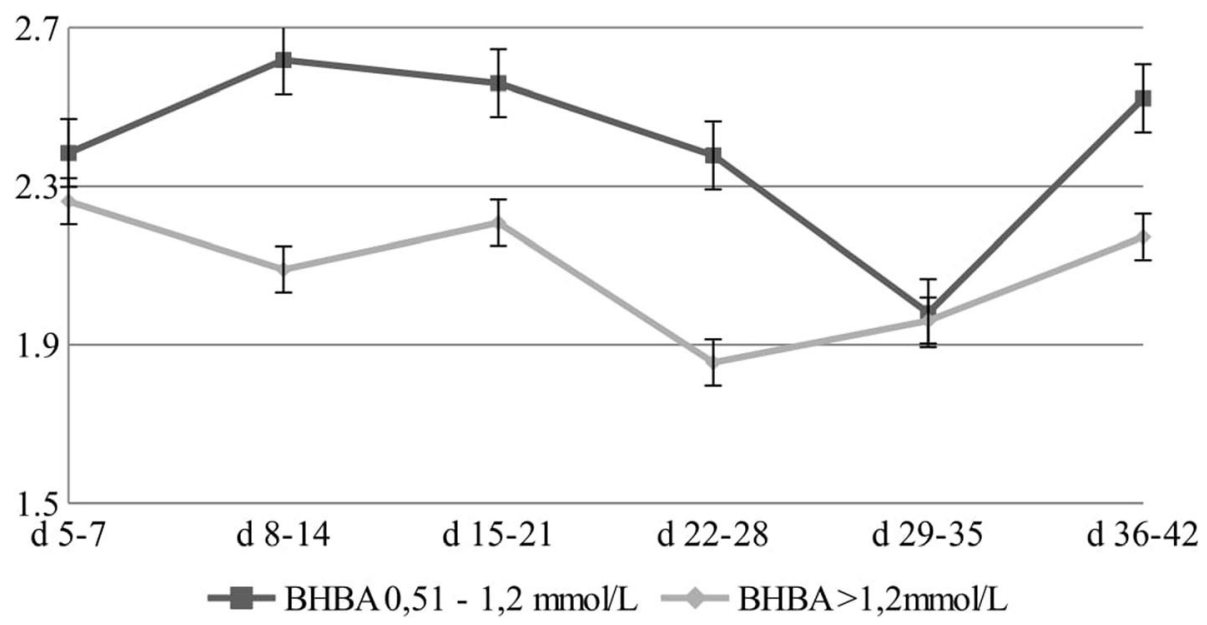

Fig. 4 Changes in the concentration of LA [g/100 g of fat] for different concentrations of BHBA

concentration $>3.60 \%$. Additionally, after analysing the results, it was also confirmed that the milk fat showed the least stability among all milk components. Other authors have come to similar conclusions [36-38].

The optimum fat/protein (F/P) ratio is 1.2-1.4. Lower values are the result of subclinical rumen acidosis, which can endanger the reproduction performance of cows and enhance the possible development of mineral metabolism disorders. On the other hand, an F/P ratio higher than 1.4 is connected with deficiency of energy and subclinical ketosis [13]. The highest F/P ratio (1.56) was demonstrated in the first period - between the fifth and seventh days of lactation in cows with a BHBA level $>1.2 \mathrm{mmol} / \mathrm{L}$ (Fig. 3). García et al. [39] reported a positive relationship between BHBA levels and the $\mathrm{F} / \mathrm{P}$ ratio $(R 2=0.42)$. Herds with ketosis problems in early lactation tend to have an increased probability of occurrence of displaced abomasum and herd removal $(>8 \%)$ in the initial phase of lactation [1]. Additionally, Toni et al. [40] concluded, that cows with an $\mathrm{F} / P>2.0$ during early lactation showed an increase in postpartum diseases such as retained placenta, metritis, and clinical endometritis.

NEB is partly caused by cows limiting their intake of dry matter during the postpartum period. The lactation phase, as well as NEB stage, significantly contribute to changes in the composition of milk fat, as well as limit the activity of individual fatty acid pathways. About 50\% of the fatty acids in milk originate from the diet, while the remaining $50 \%$ is from adipose tissue, but the adipose tissue contribution is much higher during early lactation [41]. Dairy cow in NEB is predisposed to hepatic lipidosis and ketosis, because of the inability to dispose of mobilized FA via $\beta$-oxidation or the limited capacity to export FA reesterified into TAG from the liver [42].

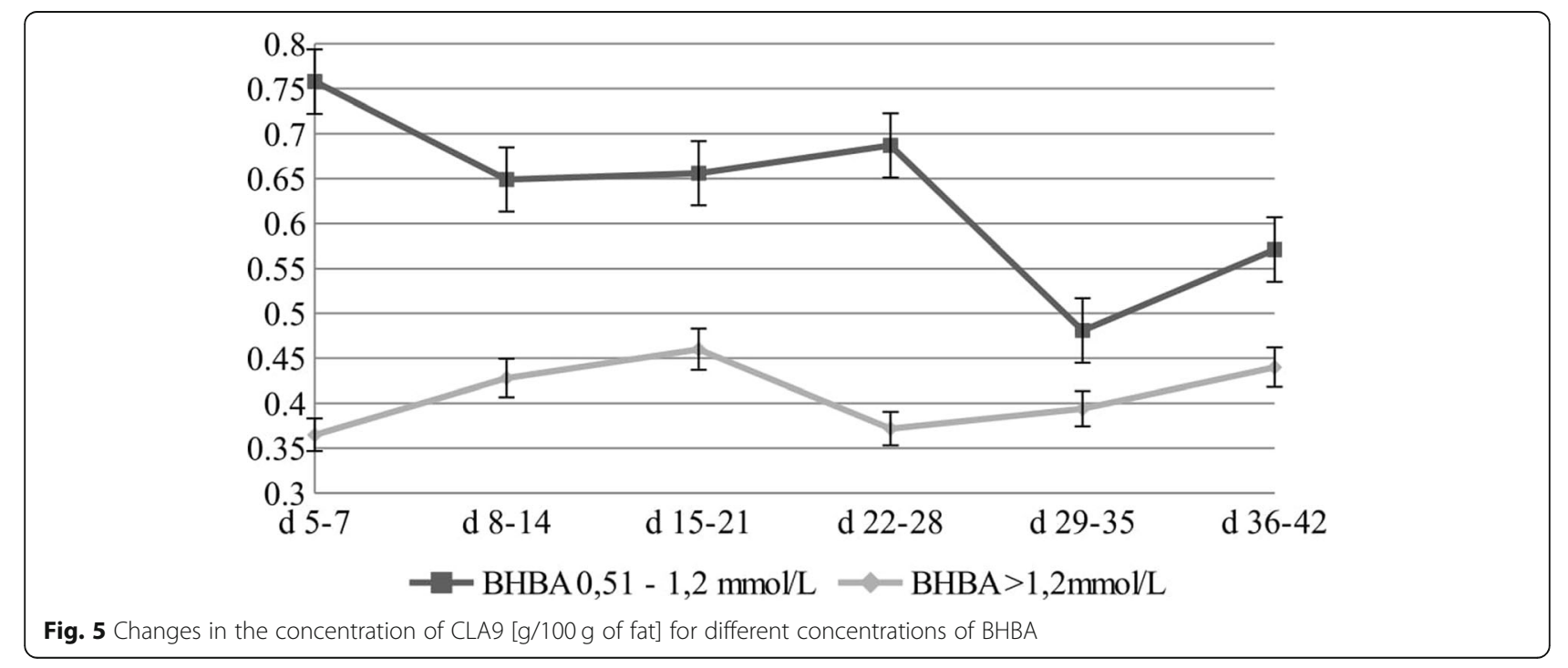




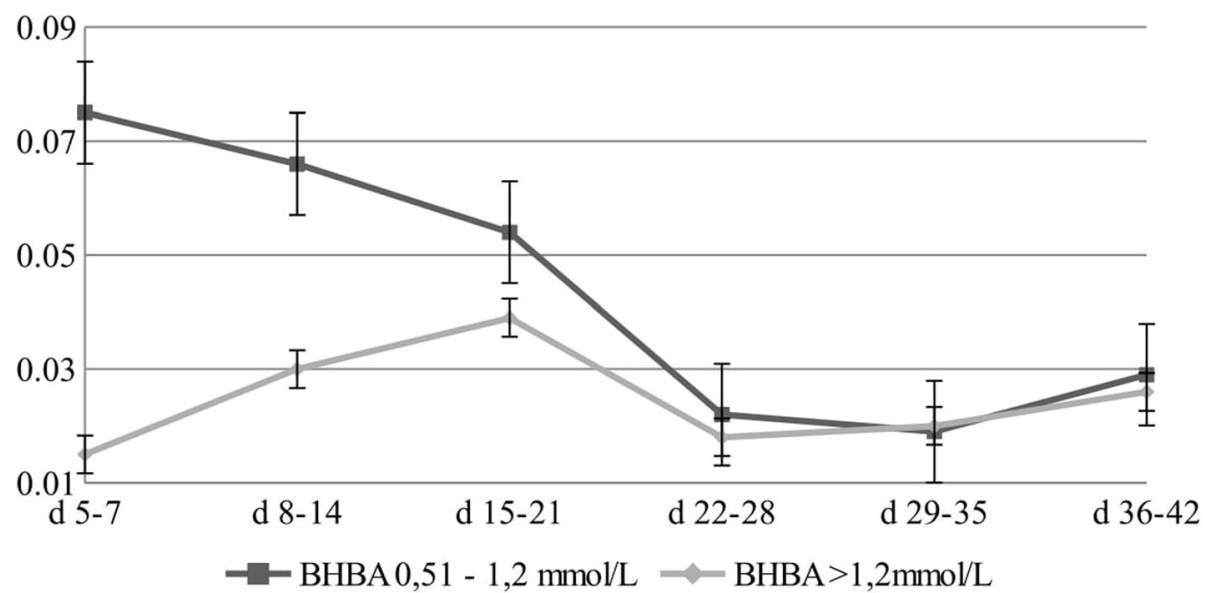

Fig. 6 Changes in the concentration of $\mathrm{CLA} 10$ [g/100 $\mathrm{g}$ of fat] for different concentrations of BHBA

Studies have shown that the concentrations of C4:0, C6: 0, C8:0, C10:0, C12:0 and C14:0 are significantly influenced by BHBA. Substrates for de novo synthesis of FA are acetate and $\beta$-hydroxybutyrate, used by the mammary epithelial cells to synthesize short- and mediumchain fatty acids and part of the 16-carbon FA [43]. Van Knegsel et al. [44] suggested that during the NEB period, the de novo synthesis of FA is reduced and the cow's body begins to use its own reserves, which is confirmed by the obtained results.

Studies have shown that the concentration of C18:2 n-6 was significantly influenced by both the lactation phase and BHBA. C18:2 n- 6 acts as a substrate for C18:1 trans11 , which is transformed into C18:2 cis-9 trans-11, as well as for long-chain fatty acids formed by desaturation and elongation [45-47]. Gross et al. [3] showed that a lowered concentration of unsaturated fatty acids was associated with the stabilization of the cows' energy balance.

Isomers $\mathrm{C} 18: 2$ cis- 9 trans- 11 are formed in ruminant tissue and the mammary glands via the action of stearoylCoA desaturase on C18:1 trans-7 and C18:1 trans-11, respectively [46, 47]. Lock and Garnsworthy [48] estimated that, the endogenous synthesis of CLA to be $>80 \%$ of the total concentration. Rumen $\mathrm{pH}$ has a significant role in keeping a viable rumen environment appropriate for $B$. fibrisolvens involved in the biohydrogenation of C18:2 n- 6 and $\mathrm{C} 18: 3 \mathrm{n}-3$. Additionally, ruminal $\mathrm{pH}$ at 6.0 or above has a positive effect on C18:1 trans-11 and C18:2 cis-9 trans-11 contents in rumen cultures [49]. On the other hand, decreased in rumen $\mathrm{pH}$ results in bacterial population changes and consequent modification end products of fermentation [50]. When ketosis occurs, high levels of ketone bodies inhibit the activity of acetyl-CoA and so decrease the transport of acetyl-CoA to ketone bodies, which may result in acetyl-CoA accumulating quickly. In this study, the level of C18:2 cis-9 trans-11 was significantly influenced by the concentration of BHBA in the blood plasma. Melendez et al. [24] also reported that early postpartum cows with a plasma BHBA level $>0.7 \mathrm{mmol} / \mathrm{L}$ tended to have a lower proportion of CLA than cows with a BHBA level $\leq 0.7 \mathrm{mmol} / \mathrm{L}$. Dietary supplementation of plant and animals oils or pasture results in substantial increases in the concentration of CLA in milk fat [51-53], as does microbial activity in the rumen [47]. In our case,

Table 2 Pearson correlations between individual components during the first week of lactation

\begin{tabular}{|c|c|c|c|c|c|c|c|c|}
\hline & Casein & Protein & Fat & LA & CLA9 & CLA10 & BHBA & NEFA \\
\hline Casein & 1 & $0.953^{a}$ & 0.054 & 0.219 & -0.039 & $-0.269^{b}$ & $-0.527^{\mathrm{a}}$ & -0.254 \\
\hline Protein & $0.953^{\mathrm{a}}$ & 1 & -0.113 & $0.404^{a}$ & 0.021 & -0.240 & $-0.577^{\mathrm{a}}$ & -0.435 \\
\hline Fat & 0.054 & -0.113 & 1 & $-0.628^{a}$ & $-0.311^{b}$ & -0.165 & $0.591^{b}$ & $0.622^{a}$ \\
\hline LA & 0.219 & $0.404^{a}$ & $-0.628^{\mathrm{a}}$ & 1 & $0.664^{a}$ & 0.213 & $-0.418^{\mathrm{a}}$ & -0.753 \\
\hline CLA9 & -0.039 & 0.021 & $-0.311^{b}$ & $0.364^{a}$ & 1 & $0.831^{a}$ & $-0.732^{\mathrm{a}}$ & -0.312 \\
\hline CLA10 & $-0.269^{b}$ & -0.240 & -0.165 & 0.213 & $0.831^{\mathrm{a}}$ & 1 & $-0.821^{a}$ & 0.044 \\
\hline BHBA & $-0.527^{a}$ & $-0.577^{a}$ & $0.591^{b}$ & $-0.418^{\mathrm{a}}$ & $-0.732^{a}$ & $-0.821^{b}$ & 1 & $0.613^{a}$ \\
\hline NEFA & -0.254 & -0.435 & $0.622^{a}$ & -0.753 & -0.312 & 0.044 & $0.613^{a}$ & 1 \\
\hline
\end{tabular}

LA C18:2 n-6, CLA9 C 18:2 cis-9 trans-11, CLA10 C18:2 trans-10 cis-12, BHBA $\beta$-hydroxybutyric acid, NEFA Nonesterified fatty acids

${ }^{\text {a }}$ Correlation significant at a 0.01 level (two-sided)

${ }^{\mathrm{b}}$ Correlation significant at a 0.05 level (two-sided) 
Table 3 Pearson correlations between individual components during the second week of lactation

\begin{tabular}{|c|c|c|c|c|c|c|c|c|}
\hline & Casein & Protein & Fat & LA & CLA9 & CLA10 & BHBA & NEFA \\
\hline Casein & 1 & $0.923^{a}$ & -0.066 & $0.228^{b}$ & $0.251^{b}$ & 0.100 & $-0.292^{\mathrm{a}}$ & -0.359 \\
\hline Protein & $0.923^{\mathrm{a}}$ & 1 & $-0.328^{\mathrm{a}}$ & $0.265^{b}$ & 0.086 & -0.035 & $-0.373^{\mathrm{a}}$ & $-0.270^{a}$ \\
\hline Fat & -0.066 & $-0.328^{a}$ & 1 & -0.015 & 0.147 & 0.217 & $0.295^{\mathrm{a}}$ & $0.490^{\mathrm{a}}$ \\
\hline LA & $0.228^{b}$ & $0.265^{b}$ & -0.015 & 1 & $0.532^{a}$ & $0.401^{\mathrm{a}}$ & $-0.553^{\mathrm{a}}$ & $-0.630^{\mathrm{a}}$ \\
\hline CLA9 & $0.251^{b}$ & 0.086 & 0.147 & $0.532^{\mathrm{a}}$ & 1 & $0.848^{\mathrm{a}}$ & $-0.520^{\mathrm{a}}$ & -0.206 \\
\hline CLA10 & 0.100 & -0.035 & 0.217 & $0.401^{a}$ & $0.848^{a}$ & 1 & $-0.635^{\mathrm{a}}$ & -0.060 \\
\hline BHBA & $-0.292^{\mathrm{a}}$ & $-0.373^{\mathrm{a}}$ & $0.295^{\mathrm{a}}$ & $-0.553^{\mathrm{a}}$ & $-0.520^{\mathrm{a}}$ & $-0.635^{\mathrm{a}}$ & 1 & $0.632^{a}$ \\
\hline NEFA & -0.359 & $-0.270^{\mathrm{a}}$ & $0.490^{a}$ & $-0.630^{\mathrm{a}}$ & -0.206 & -0.060 & $0.632^{\mathrm{a}}$ & 1 \\
\hline
\end{tabular}

LA C18:2 n-6, CLA9 C 18:2 cis-9 trans-11, CLA10 C 18:2 trans-10 cis-12, BHBA $\beta$-hydroxybutyric acid, NEFA Nonesterified fatty acids

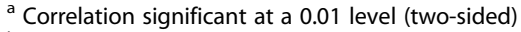

${ }^{\mathrm{b}}$ Correlation significant at a 0.05 level (two-sided)

there was nothing in the diet composition to suggest a bypass form, nor was there an excessive amount of dietary fat that would be available to microbes in the rumen to generate CLA. Therefore, the decline of CLA concentrations in milk is likely due to a lower supply from the rumen.

Concentrations of NEFAs and BHBA are the basic elements of the metabolic profile, which are used in the diagnostics of metabolic diseases [50]. However, Duffield [54], reported that the use of NEFA is a better indicator of energy imbalance in prepartum animals than BHBA, but BHBA is more useful postpartum. In the present study, a significant positive correlation was established between NEFA and BHBA (Tables 2 and 3). Duffield [54] demonstrated, that a $1 \%$ increase in milk fat was associated with 2-fold increase in the risk of subclinical ketosis. Additionally, changes in rumen biohydrogenation increase the molar proportions of trans fatty acids that inhibit milk fat synthesis $[55,56]$. The increased in the concentration of BHBA and NEFA due to the mobilization of endogenous lipids, leads to a decrease in the percentage of milk protein $[57,58]$. Pearson correlation analysis showed a significant negative correlation between BHBA levels and the levels of selected functional fatty acids (Tables 2 and 3 ).

\section{Conclusion}

Despite the advantages or disadvantages of urine or milk tests, none of them have perfect sensitivity and specificity compared to the "gold standard" test of blood BHBA. Therefore, it is important that new tests with greater sensitivity and specificity need to be developed. As shown in the study results, the high concentration of BHBA in postpartum cows was associated with significantly lower levels of LA, CLA9 and CLA10.Strong negative correlation in the first week of lactation was found between BHBA $\mathrm{x}$ CLA9 $(-0.732)$ and BHBA $x$ CLA10 (-0.821), and in the second week of lactation between BHBA x CLA9 $(-0.520)$ and BHBA x CLA10 (-0.635). Additionally, analytical devices equipped with Fourier Transform Spectrometer
(FTIR) allow to determine parameters such as: fat, protein, lactose and fatty acids: CLA9, MUFA, PUFA, SFA in a very short time. Fourier transform infrared spectrum of milk composition could be used by breeders to predict blood BHBA levels, because these data are available during Dairy Herd Improvement testing. Limiting the frequency and amount of blood sampling for laboratory analysis, and replacing them with standard milk analysis using the FTIR technique will improve welfare by reducing the number of stress factors, as well as influence faster diagnostics of metabolic disorders. The demonstrated negative relationship between plasma BHBA levels in blood and CLA levels in milk remains another reason to consider the fundamental prevention of high ketone levels when the dairy industry is looking for milk and its derivatives with high C18:2 cis-9 trans-11 and C18:2 trans-10 cis-12 levels.

Due to the obtained high level of correlation coefficient, repeatability and representative number of samples, it can be stated that C18:2 cis-9 trans- 11 and C18:2 trans-10 cis-12 are useful markers for the early diagnosis of elevated blood levels of BHBA in postpartum Polish Holstein-Friesian cows.

\section{Methods \\ Study design}

The experimental procedures were carried out according to the regulations of the Polish Council on Animal Care and were approved by the Warsaw University of Life Sciences Care Committee. The experiment was carried out at the experimental dairy farm of the Warsaw University of Life Sciences (WULS), in which a herd of approximately 350 cows was kept in free stall housing system, with an average performance exceeding $10,000 \mathrm{~kg}$ of milk per lactation. Table 4 shows the lactating cows' nutrient requirement.

The cows' feeding regime was based on the total mixed ration (TMR) diet (ad libitum) (Table 5). Cows were fed twice a day. Dry matter intake was determined weekly by weighing remaining orts. 
Table 4 Lactating cows' nutrient requirement

\begin{tabular}{ll}
\hline Cow description & \\
Cow weight & $680 \mathrm{~kg}$ \\
Lactation days & 50 \\
Milk production & $38 \mathrm{~kg}$ \\
Milk fat & $4.00 \%$ \\
Milk protein & $3.07 \%$ \\
Nutrient requirement & \\
NEL (Mcal/day) & 39.5 \\
Metabolic protein (g/day) & 2589 \\
Ca (g/day) & 65 \\
F (g/day) & 59 \\
K (g/day) & 228 \\
\hline
\end{tabular}

NEL Netto energy lactation, $\mathrm{Ca}$ Calcium, $F$ Phosphorus, $K$ Potassium

During the health monitoring procedure of all herd (360 cows), 85 cows were used in this study. These cows were multiparous, in the second lactation, and had an average body weight of $682.45 \mathrm{~kg}$. Based on the clinical symptoms (reduced feed intake and milk yield) and serum BHBA and NEFA concentration, this group of cows included 40 ketotic cows whose serum BHBA concentration was $>1.2 \mathrm{mmol} / \mathrm{L}$ and NEFA $\geq 0.7 \mathrm{mmol} / \mathrm{L}$ at 5-7 days postpartum, and 45 healthy cows whose serum BHBA concentration was $0.51-1.2 \mathrm{mmol} / \mathrm{L}$ and NEFA < $0.7 \mathrm{mmol} / \mathrm{L}$ at $5-7$ days postpartum. The characteristics of the ketotic and healthy cows are presented in Table 6 .

Samples of milk and blood were collected from the cows for laboratory analyses at weekly intervals. Samples were taken at six time points: between days $5-7,8-14$, $15-21,22-28,29-35$, and $36-42$, resulting in 510 samples of both milk and blood.

Body condition score was assessed once a week by BCS-5 method describing by Edmonson et al. [59] and Wildman et al. [60].

The cows were milked daily at 05:30 and 17:30, and the milk yield was recorded at each milking. During the experiment, milk samples were obtained from each cow from the morning and evening milking. The samples were combined, giving a representative sample. The milk was placed in sterile bottles, preserved with Mlekostat $\mathrm{CC}$ and immediately transported to the Cattle Breeding Division (Milk Testing Laboratory of WULS) for compositional analysis.

Blood samples $(10 \mathrm{~mL})$ were taken from each cow by jugular vein puncture using tubes (Vacuette, Germany) containing potassium-EDTA (K3EDTA, $1.8 \mathrm{~g} / \mathrm{L}$ of blood) as an anticoagulant. Blood samples were centrifuged at $1800 \times \mathrm{g}$ at $4^{\circ} \mathrm{C}$ for $15 \mathrm{~min}$, and the supernatant was immediately transported to the Veterinary Centre of WULS for the analysis of blood plasma metabolites (BHBA and NEFA).
Table 5 Ingredient and chemical composition of TMR

\begin{tabular}{|c|c|}
\hline & TMR diet \\
\hline \multicolumn{2}{|l|}{ Ingredient [kg/d DM] } \\
\hline Maize silage & 9.12 \\
\hline Alfalfa silage & 3.50 \\
\hline Corn silage & 2.35 \\
\hline Soybean meal & 2.62 \\
\hline Pasture ground chalk & 0.20 \\
\hline VIT-RA BML- vitamin mix & 0.20 \\
\hline Salt & 0.05 \\
\hline Rapeseed meal & 2.07 \\
\hline Magnesium oxide & 0.07 \\
\hline \multicolumn{2}{|l|}{ Chemical composition [g/kg DM] } \\
\hline Ash & 5.25 \\
\hline Crude protein & 15.85 \\
\hline Fat & 4.89 \\
\hline Starch & 289.21 \\
\hline Sugar & 77.45 \\
\hline ADF & 30.02 \\
\hline NDF & 41.21 \\
\hline $\mathrm{Ca}$ & 0.90 \\
\hline P & 0.61 \\
\hline NEL (Mcal/kg) & 1.67 \\
\hline Total, kg of DM (offered) & 20.18 \\
\hline Daily intake (kg) & 19.95 \\
\hline Average milk production (kg) & 34.18 \\
\hline UFL balance (\%) & 3.25 \\
\hline PDIN & 2.58 \\
\hline PDIE & -2.22 \\
\hline
\end{tabular}

VIT-RA BML (values per kg): $150 \mathrm{~g} \mathrm{Ca}, 100 \mathrm{~g} \mathrm{P}, 50 \mathrm{~g} \mathrm{Na}, 40 \mathrm{~g} \mathrm{Mg}, 9000 \mathrm{mg} \mathrm{Zn}$, $7000 \mathrm{mg} \mathrm{Mn}, 1000 \mathrm{mg} \mathrm{Cu}, 100 \mathrm{mg}$ J, $50 \mathrm{mg} \mathrm{Se}, 1,200,000$ IU vitamin A, 120000 IU vitamin $D_{3}, 5000 \mathrm{mg}$ vitamin $E_{1}, 93 \mathrm{mg}$ vitamin $K, 80 \mathrm{mg}$ vitamin $B_{1}, 160 \mathrm{mg}$ vitamin $B_{6}, 110 \mathrm{mg}$ vitamin $B_{2}, 1000 \mu \mathrm{g}$ vitamin $B_{12}$ (PPH VITRA, Kusowo, Poland)

TMR Total mixed ration, DM Dry matter, ADF Acid detergent fiber, NDF Neutral detergent fiber, NEL Netto energy lactation, $C a$ Calcium, $F$ Phosphorus, $K$ Potassium, UFL Unit of milk production, PDIN Protein digested in the small intestine when rumen-fermentable nitrogen is limiting, PDIE Protein digested in the small intestine when rumen-fermentable energy is limiting

Table 6 Characteristics of healthy and ketotic cows

\begin{tabular}{lllllll}
\hline Item & $\begin{array}{l}\text { Ketosis } \\
(n=40)\end{array}$ & & & $\begin{array}{l}\text { Healthy } \\
(n=45)\end{array}$ & & P-value \\
\cline { 2 - 3 } & LSM & SEM & & LSM & SEM & \\
\hline BW & $648 \mathrm{~kg}$ & 0.052 & $694 \mathrm{~kg}$ & 0.053 & 0.012 \\
Milk yield & $33.8 \mathrm{~kg} /$ day & 0.118 & & $34.1 \mathrm{~kg} /$ day & 0.123 & 0.456 \\
DMI & $18.45 \mathrm{~kg} /$ day & 0.173 & & $21.86 \mathrm{~kg} /$ day & 0.119 & 0.036 \\
BCS & 2.32 & 0.108 & & 3.22 & 0.065 & 0.025 \\
NEFA & $1.22 \mathrm{mmol} / \mathrm{L}$ & 0.082 & & $0.35 \mathrm{mmol} / \mathrm{L}$ & 0.114 & $<0.001$ \\
BHBA & $1.43 \mathrm{mmol} / \mathrm{L}$ & 0.063 & & $0.68 \mathrm{mmol} / \mathrm{L}$ & 0.088 & $<0.001$ \\
\hline
\end{tabular}

$B W$ Body weight, DMI Dry matter intake, BCS Body condition score, NEFA Nonesterified fatty acids, BHBA $\beta$-hydroxybutyric acid, $L S M$ Least square of mean, SEM Standard error of LSM 


\section{Chemical analysis}

The basic parameters of milk: fat, protein, and casein contents, were determined by automated infrared analysis using a Milkoscan FT 120 analyser (Foss Electric, Hillerød, Denmark).

The level of BHBA and NEFA was determined using a Biochemical analyser BS800M (PZ Cormay, Warsaw, Poland).

Fatty acid methylation was performed according to the trans-esterification method EN ISO 5509 [61]. Individual fatty acids were identified in crude fat using an Agilent 7890A GC (Agilent, Waldbronn, Germany) according to Puppel et al. [53]. Each peak was identified using pure methyl ester standards: FAME Mix RM-6, Lot LB 68242; Supelco 37 Comp. FAME Mix, Lot LB 68887; Methyl linoleate, Lot 094 K1497; CLA Conjugated (9Z, 11E), Lot BCBV3726 (Supelco, Bellefonte, PA, USA).

\section{Statistical analysis}

The data obtained were statistically analysed using the IBM SPSS 23.0 package [62]. The distribution of the milk chemical composition and selected fatty acids were checked using the Shapiro-Wilk test. ANOVA analysis was used to establish the influence of the lactation phase on milk chemical composition and the level of selected fatty acids. The changes in concentration of selected fatty acids in regard to BHBA blood level and lactation stage were established by multivariate analysis.

The following statistical model was used:

$$
\mathrm{Y}=\mu+\mathrm{A}_{\mathrm{i}}+\mathrm{B}_{\mathrm{j}}+(\mathrm{AxB})_{\mathrm{ij}}+\mathrm{e}_{\mathrm{ijk}}
$$

where $\mu$ - mean, $A_{i}-$ day in lactation, $B_{j}-B H B A$ concentration, $A x B$ - interaction between day in lactation and BHBA concentration, $\mathrm{e}_{\mathrm{ij}}-$ random error. Only the interactions between factors whose influence was statistically significant $(P \leq 0.01$ or $P \leq 0.05)$ were considered. The level of significance was determined after performing preliminary statistical analyses.

Pearson correlation quantifies the degree of linear relationship between two variables $x$ and $y$, and has been used to describe correlation between: casein, protein, fat, LA, CLA9, CLA10, BHB and NEFA.

\section{Abbreviations}

BHBA: $\beta$-hydroxybutyric acid; CLA10: C18:2 trans-10 cis-12; CLA9: C18:2 cis-9 trans-11; LA: C18:2 n-6; NEFA: Nonesterified fatty acids

\section{Acknowledgments}

Not applicable.

\section{Authors' contributions}

KP- Conceptualization, Data curation, Formal analysis, Investigation, Methodology, Project administration, Writing - original draft, Writing review \& editing, MG- Roles Conceptualization, Investigation, Methodology, Writing - original draft, Writing - review \& editing, PS- Formal analysis, GGWriting - original draft, JS- Formal analysis, MK-S- Formal analysis, MB- Formal analysis, TP- Formal analysis, AK- Formal analysis, BK- Investigation, Project administration, Supervision, Validation. All authors read and approved the final manuscript.

\section{Funding}

Financial support for this study was obtained from the project NN 31155 8840 entitled "Relationship between concentration of bioactive substances in milk during standard lactation and blood biochemical parameters of high yielding Polish Holstein-Friesian cows" provided by the National Science Centre. The funding body was represented by one of the Authors (BK), who has lifelong specific competence in the present research field and participated to the investigation, project administration, supervision and validation. In particular, the funding body patronized the study.

\section{Availability of data and materials}

All data generated or analyzed during the study are included in this published article. The datasets used and/or analyzed in the current study are available from the corresponding author on reasonable request.

\section{Ethics approval and consent to participate}

The experimental procedures were carried out according to the regulations of the Polish Council on Animal Care and were approved by the Warsaw University of Life Sciences Care Committee.

\section{Consent for publication}

Not applicable.

\section{Competing interests}

The authors declare that they have no competing interests.

Received: 5 April 2019 Accepted: 3 October 2019

Published online: 25 October 2019

\section{References}

1. Oetzel GR. Herd-level ketosis-diagnosis and risk factors. In: Preconference Seminar 7C: Dairy Herd Problem Investigation Strategies: Transition Cow Troubleshooting AMERICAN ASSOCIATION OF BOVINE PRACTITIONERS 40th Annual Conference. Vancouver; 2007.

2. van der Drift SGA, Houweling M, Schonewille JT, Tielens AGM, Jorritsma R. Protein and fat mobilization and associations with serum beta-hydroxybutyrate concentrations in dairy cows. J Dairy Sci. 2012;95(9):4911-20.

3. Gross J, van Dorland HA, Bruckmaier RM, Schwarz FJ. Milk fatty acid profile related to energy balance in dairy cows. J Dairy Res. 2011;78(4):479-88.

4. Suburu J, Shi LH, Wu JS, Wang SH, Samuel M, Thomas MJ, Kock ND, Yang GY, Kridel S, Chen YQ. Fatty acid synthase is required for mammary gland development and milk production during lactation. Am J Physiol Endocrinol Metab. 2014:306(10):1132-43.

5. Volpe JJ, Marasa JC. Hormonal-regulation of fatty-acid synthetase, acetyl-Coa carboxylase and fatty-acid synthesis in mammalian adipose-tissue and liver. Biochim Biophys Acta. 1975;380(3):454-72.

6. Berg JM, Tymoczko JL, Stryer L. Acetyl coenzyme A carboxylase plays a key role in controlling fatty acid metabolism. In: Biochemistry 5th edition. New York: W.H. Freeman; 2002.

7. Duncan RE, Ahmadian M, Jaworski K, Sarkadi-Nagy E, Sul HS. Regulation of lipolysis in adipocytes. Annu Rev Nutr. 2007;27:79-101.

8. Hostens M, Fievez V, Leroy JLMR, Van Ranst J, Vlaeminck B, Opsomer G. The fatty acid profile of subcutaneous and abdominal fat in dairy cows with left displacement of the abomasum. J Dairy Sci. 2012;95(7):3756-65.

9. Jorjong S, van Knegsel ATM, Verwaeren J, Lahoz MV, Bruckmaier RM, De Baets B, Kemp B, Fievez V. Milk fatty acids as possible biomarkers to early diagnose elevated concentrations of blood plasma nonesterified fatty acids in dairy cows. J Dairy Sci. 2014;97(11):7054-64.

10. Jorjong S, van Knegsel ATM, Verwaeren J, Bruckmaier RM, De Baets B, Kemp $\mathrm{B}$, Fievez V. Milk fatty acids as possible biomarkers to diagnose hyperketonemia in early lactation. J Dairy Sci. 2015;98(8):5211-21.

11. Mann S, Nydam DV, Lock AL, Overton TR, Mcart JAA. Short communication: association of milk fatty acids with early lactation hyperketonemia and elevated concentration of nonesterified fatty acids. J Dairy Sci. 2016;99(7): $5851-7$

12. Stoop WM, Bovenhuis $H$, Heck JML, van Arendonk JAM. Effect of lactation stage and energy status on milk fat composition of Holstein-Friesian cows. J Dairy Sci. 2009;92(4):1469-78. 
13. Čejna V, Chládek G. The importance of monitoring changes in milk fat to milk protein ratio in Holstein cows during lactation. J Cen Eur Agric. 2006; 6(4):539-46.

14. Puppel K, Solarczyk P, Kuczynska B, Madras-Majewska B. Oleic acid as a biomarker for early diagnosis of elevated blood levels of non-esterified fatty acids and beta-hydroxybutyric acid in the early stages of lactation in highyielding Polish Holstein cows. Anim Sci Pap Rep. 2017;35(4):387-96.

15. Foster DW. Malonyl-CoA: the regulator of fatty acid synthesis and oxidation. J Clin Invest. 2012;122(6):1958-9.

16. Grabacka M, Pierzchalska M, Dean M, Reiss K. Regulation of ketone body metabolism and the role of PPAR alpha. Int J Mol Sci. 2016;17(12):2093. https://doi.org/10.3390/ijms17122093.

17. Gołębiewski M. Badanie przydatności zmodyfikowanej oceny kondycji krów mlecznych w zarządzaniu ich stadem ze szczególnym uwzględnieniem parametrów produkcyjnych, funkcjonowania układu rozrodczego oraz zdrowia zwierząt. In: Edited by Sciences WULS. Warsaw; 2017.

18. Grum DE, Drackley JK, Younker RS, LaCount DW, Veenhuizen JJ. Nutrition during the dry period and hepatic lipid metabolism of periparturient dairy cows. J Dairy Sci. 1996;79(10):1850-64.

19. CadornigaValino C, Grummer RR, Armentano LE, Donkin SS, Bertics SJ. Effects of fatty acids and hormones on fatty acid metabolism and gluconeogenesis in bovine hepatocytes. J Dairy Sci. 1997;80(4):646-56.

20. Xu C, Wang Z, Liu GW, Li XB, Xie GH, Xia C, Zhang HY. Metabolic characteristic of the liver of dairy cows during ketosis based on comparative proteomics. Asian Australas J Anim Sci. 2008;21(7):1003-10.

21. Puppel K, Kuczyńska B. Metabolic profiles of cow's blood; a review. J Sci Food Agric. 2016;96(13):4321-8.

22. Ospina PA, Nydam DV, Stokol T, Overton TR. Associations of elevated nonesterified fatty acids and beta-hydroxybutyrate concentrations with early lactation reproductive performance and milk production in transition dairy cattle in the northeastern United States. J Dairy Sci. 2010;93(4):1596-603.

23. Walsh RB, Walton JS, Kelton DF, LeBlanc SJ, Leslie KE, Duffield TF. The effect of subclinical ketosis in early lactation on reproductive performance of postpartum dairy cows. J Dairy Sci. 2007;90(6):2788-96.

24. Melendez P, Pinedo P, Bastias J, Marin MP, Rios C, Bustamante C, Adaro N, Duchens $\mathrm{M}$. The association between serum ß-hydroxybutyrate and milk fatty acid profile with special emphasis on conjugated linoleic acid in postpartum Holstein cows. BMC Vet Res. 2016;12(1):50. https://doi.org/10. 1186/s12917-016-0679-7.

25. Madreseh-Ghahfarokhi S, Dehghani-Samani A, Dehghani-Samani A. Ketosis (acetonaemia) in dairy cattle farms: practical guide based on importance, diagnosis, prevention and treatments. J Dairy Vet Anim Res. 2018;7(6):299-302.

26. Geishauser T, Leslie K, Tenhag J, Bashiri A. Evaluation of eight cow-side ketone tests in milk for detection of subclinical ketosis in dairy cows. J Dairy Sci. 2000;83(2):296-9.

27. Enjalbert F, Nicot MC, Bayourthe C, Moncoulon R. Ketone bodies in milk and blood of dairy cows: relationship between concentrations and utilization for detection of subclinical ketosis. J Dairy Sci. 2001;84(3):583-9.

28. Carrier J, Stewart S, Godden S, Fetrow J, Rapnicki P. Evaluation and use of three cowside tests for detection of subclinical ketosis in early postpartum cows. J Dairy Sci. 2004;87(11):3725-35.

29. Sun LW, Zhang HY, Wu L, Shu S, Xia C, Xu C, Zheng JS. H-1-nuclear magnetic resonance-based plasma metabolic profiling of dairy cows with clinical and subclinical ketosis. J Dairy Sci. 2014;97(3):1552-62.

30. Song YX, Li N, Gu JM, Fu SP, Peng ZC, Zhao CX, Zhang YM, Li XB, Wang Z, Li XW, et al. beta-Hydroxybutyrate induces bovine hepatocyte apoptosis via an ROS-p38 signaling pathway. J Dairy Sci. 2016;99(11):9184-98.

31. Ikonen T, Morri S, Tyriseva AM, Ruottinen O, Ojala M. Genetic and phenotypic correlations between milk coagulation properties, milk production traits, somatic cell count, casein content, and pH of milk. J Dairy Sci. 2004;87(2):458-67.

32. Pecka E, Zachwieja A, Zawadzki W, Kaszuba J, Tumanowicz J. Wpływ stadium laktacji na wydajność i właściwości fizykochemiczne oraz skład podstawowy mleka krów pierwiastek. Acta Sci Pol Med Vet. 2012;11(3):5-14.

33. Pralle $\mathrm{R}$, Weigel $\mathrm{K}$, White $\mathrm{H}$. Predicting blood $\beta$-hydroxybutyrate using milk Fourier transform infrared spectrum, milk composition, and producerreported variables with multiple linear regression, partial least squares regression, and artificial neural network. J Dairy Sci. 2018;101(5):4378-87.

34. Heuer C, Van Straalen WM, Schukken YH, Dirkzwager A, Noordhuizen JPTM. Prediction of energy balance in a high yielding dairy herd in early lactation: model development and precision. Livest Prod Sci. 2000;65(1-2):91-105.
35. Duffield TF, Lissemore KD, McBride BW, Leslie KE. Impact of hyperketonemia in early lactation dairy cows on health and production. J Dairy Sci. 2009; 92(2):571-80.

36. Barlowska J, Litwinczuk Z, Krol J, Topyla B. Technological usefulness of milk of cows of six breeds maintained in Poland relative to a lactation phase. Pol J Food Nutr Sci. 2006;15-56:17-21.

37. Sakowski T, Kuczynska B, Puppel K, Metera E, Sloniewski K, Barszczewski J. Relationships between physiological indicators in blood, and their yield, as well as chemical composition of milk obtained from organic dairy cows. J Sci Food Agric. 2012;92(14):2905-12.

38. Kuczyńska B, Nałęcz-Tarwacka T, Puppel K. Bioaktywne składniki jako wyznacznik jakości prozdrowotnej mleka. Med Rodzinna. 2013;1:11-8.

39. Garcia CAC, Montiel RLA, Borderas TF, Girard V. Relationship between betahydroxybutyrate and the fat: protein ratio of milk during early lactation in dairy cows. Arch Med Vet. 2015;47(1):21-5.

40. Toni F, Vincenti L, Grigoletto L, Ricci A, Schukken YH. Early lactation ratio of fat and protein percentage in milk is associated with health, milk production, and survival. J Dairy Sci. 2011;94(4):1772-83.

41. Palmquist $D$, Beaulieu $A D$, Barbano $D$. Feed and animal factors influencing milk fat composition. J Dairy Sci. 1993;76(6):1753-71.

42. Sterk A-R. Ruminal fatty acid metabolism: altering rumen biohydrolgenation to improve milk fatty acid profile of dairy cows. the Netherlands: Thesis, Wageningen University; 2011. https://pdfs.semanticscholar.org/caf6/3ef4cd3 f29a197f3fefcda63d8723f5788a0.pdf?_ga=2.261691021.123340471.157001 0783-368543002.1568824074

43. Lock AL, Bauman DE. Modifying milk fat composition of dairy cows to enhance fatty acids beneficial to human health. Lipids. 2004;39(12):1197-206.

44. van Knegsel AT, Van den Brand H, Dijkstra J, Tamminga S, Kemp B. Effect of dietary energy source on energy balance, production, metabolic disorders and reproduction in lactating dairy cattle. Reprod Nutr Dev. 2005;45(6):665-88.

45. Nogalski Z, Wronski M, Sobczuk-Szul M, Mochol M, Pogorzelska P. The effect of body energy reserve mobilization on the fatty acid profile of milk in high-yielding cows. Asian Australas J Anim Sci. 2012;25(12):1712-20.

46. Shingfield KJ, Wallace RJ. Synthesis of conjugated linoleic acid in ruminants and humans. Rsc Catal Ser. 2014;19:1-65.

47. Bauman D, Baumgard L, Corl B, Griinari DJ. Biosynthesis of conjugated linoleic acid in ruminants. In: Proc. Am. Soc. Anim. Sci.; 1999. p. 1-14.

48. Lock AL, Garnsworthy PC. Independent effects of dietary linoleic and linolenic fatty acids on the conjugated linoleic acid content of cows' milk. Anim Sci. 2002;74:163-76.

49. Martin SA, Jenkins TC. Factors affecting conjugated linoleic acid and trans-C18:1 fatty acid production by mixed ruminal bacteria. J Anim Sci. 2002; 80(12):3347-52.

50. Gozho GN, Plaizier JC, Krause DO, Kennedy AD, Wittenberg KM. Subacute ruminal acidosis induces ruminal lipopolysaccharide endotoxin release and triggers an inflammatory response. J Dairy Sci. 2005;88(4):1399-403.

51. Puppel K, Nalecz-Tarwacka T, Kuczynska B, Golebiewski M, Kordyasz M, Grodzki $H$. The age of cows as a factor shaping the antioxidant level during a nutritional experiment with fish oil and linseed supplementation for increasing the antioxidant value of milk. J Sci Food Agric. 2012;92(12):2494-9.

52. Puppel K, Kuczynska B, Nalecz-Tarwacka T, Grodzki H. Influence of linseed variety on fatty acid profile in cow's milk. J Sci Food Agric. 2013;93(9):2276-80.

53. Puppel K, Sakowski T, Kuczyńska B, Grodkowski G, Gołębiewski M, Barszczewski J, et al. Degrees of antioxidant protection: a 2-year study of the bioactive properties of organic milk in Poland. J Food Sci. 2017;82(2): 523-8.

54. Duffield T. Subclinical ketosis in lactating dairy cattle. Vet Clin North Am Food Anim Pract. 2000;16(2):231-53.

55. Griinari JM, Dwyer DA, McGuire MA, Bauman DE, Palmquist DL, Nurmela KW. Trans-octadecenoic acids and milk fat depression in lactating dairy cows. J Dairy Sci. 1998;81(5):1251-61.

56. Kolver ES, de Veth MJ. Prediction of ruminal $\mathrm{pH}$ from pasture-based diets. J Dairy Sci. 2002;85(5):1255-66.

57. Mulligan FT, O'Grady L, Rice DA, Doherty ML. A herd health approach to dairy cow nutrition and production diseases of the transition cow. Anim Reprod Sci. 2006;96(3-4):331-53.

58. Buttchereit $N$, Stamer $E$, Junge W, Thaller $G$. Evaluation of five lactation curve models fitted for fat:protein ratio of milk and daily energy balance. J Dairy Sci. 2010;93(4):1702-12.

59. Edmonson AJ, Lean IJ, Weaver LD, Farver T, Webster G. A body condition scoring chart for Holstein dairy cows. J Dairy Sci. 1989;72:68-78. 
60. Wildman EE, Jones GM, Wagner PE, Boman RL, Troutt HF Jr, Lesch TN. A dairy cow body condition scoring system and its relationship to selected production characteristics. J Dairy Sci. 1982;65:495-501.

61. ISO P. Animal and vegetable fats and oils-preparation of methyl esters of fatty acids. Polish Stand Method PN-EN ISO. 2000;5509:2000.

62. IBM Crop. Released IBM SPSS for Windows, Version 23.0. Armonk: IBM Corp.; 2017.

\section{Publisher's Note}

Springer Nature remains neutral with regard to jurisdictional claims in published maps and institutional affiliations.

Ready to submit your research? Choose BMC and benefit from:

- fast, convenient online submission

- thorough peer review by experienced researchers in your field

- rapid publication on acceptance

- support for research data, including large and complex data types

- gold Open Access which fosters wider collaboration and increased citations

- maximum visibility for your research: over $100 \mathrm{M}$ website views per year

At $\mathrm{BMC}$, research is always in progress.

Learn more biomedcentral.com/submissions 